\title{
THIRD OUTBREAK OF TRICHINELLOSIS CAUSED BY CONSUMPTION OF HORSE MEAT IN ITALY
}

\author{
E. POZIO*, O. CAPPELli**, L. MARChESI**, P. VALERI**, \\ P. ROSSI*
}

\begin{abstract}
SUMMARY. The clinical and epidemiological aspects of the largest Italian outbreak of human trichinellosis which occurred in Northern Italy in August 1986 are reported. About 300 people who ate raw horse meat were involved. The clinical and biological aspects of 161 patients were studied. None died. The causal parasite, isolated from a patient, was identified through isoenzymatic typing as Trichinella nelsoni. Fever, œdema, myalgia and headache were the most common signs and symptoms. The Fluorescent Antibody Test (FAT) proved positive for 96 percent of the patients showing clinical manifestations. Essential laboratory data are reported.
\end{abstract}

Key-words: Human trichinellosis. Horse Meat. Trichinella nelsoni. Clinical and Biological Aspects.

\section{Troisième épidémie de trichinellose due à la consommation de viande de cheval en Italie.}

RÉSUMÉ. Les aspects cliniques et épidémiologiques de l'épidémie de trichinellose humaine qui est survenue en Italie du Nord en août 1986, sont rapportés.

Cette épidémie concernant 300 personnes qui avaient consommé de la viande de cheval crue, est la plus importante signalée jusqu'ici en Italie.

Les signes cliniques et biologiques de 161 patients ont été étudiés. Il n’y a eu aucun décès. Le parasite cause de l'épidémie a été isolé chez l'un des patients et le typage enzymatique a permis de l'identifier comme Trichinella nelsoni. Fièvre, œedème, myalgies et maux de tête ont été les signes les plus communément observés. Le test d'immunofluorescence indirecte est trouvé positif chez $96 \%$ des malades qui présentaient des manifestations cliniques. Les données essentielles du laboratoire sont rapportées.

Mots-clés : Trichinellose humaine, Viande de cheval. Trichinella nelsoni. Aspects cliniques et biologiques.

\section{Introduction}

Human trichinellosis caused by the ingestion of horse meat occurred for the first time in Northern Italy in 1975 (Mantovani et al., 1980). Successively there was an outbreak in 1976 in Paris (Motyka, 1976 ; Bourée et al., 1979) ; in 1984 in Nor-

* Laboratorio di Parassitologia, Istituto Superiore di Sanità, viale Regina Elena, 299, 00161 Rome, Italia.

** Unità Sanitaria Locale N. 5, Fidenza, Parma.

Accepté le 31 août 1987. 
thern Italy (Parravicini et al., 1986); and in 1985 in France (Ancelle et al., 1986).

We report an outbreak affecting about 300 people in Salsomaggiore Terme (Parma Province, Northern Italy) in September-October 1986.

All patients had eaten raw horse meat from 22 to 25 August 1986, bought in a butcker's shop which sells only horse meat. The infected horse, slaughtered in Val Madrera (Como Province, Northern Italy) on 19 August, came from a stock of 50 imported horses (28 from Yugoslavia and 22 from Poland).

\section{Patients and Methods}

From 15 September to 5 October 1986 many family physicians of Salsomaggiore Terme examined many people with an uncommon symptomatology. Eight people with a serious illness were hospitalized in Fidenza and Parma hospitals. Many possible diagnoses were considered: influenza, food poisoning, muscle rheumatism, periarteritis nodosa, eosinophilic leukemia, and others. Some physicians thought of intestinal helminthiases but faecal examinations were negative. Lastly, a family physician, who had read a paper on the Trichinella epidemic in 1985 in France, made the correct clinical diagnosis, which was confirmed parasitologically (see Results). There is no hospital in Salsomaggiore, so the health authority established a health centre for collection of epidemiological data and blood samples, and for clinical diagnosis and treatment. 149 patients went into this centre, the others (about 140) preferred to follow clinical diagnosis and treatment by family physicians (personal communications of family physicians of Salsomaggiore).

Four people, resident in other cities or villages (Rome, Milan, Polesine Parmense and Tabiano), but who had eaten the infected horse meat from 22 to 25 August in Salsomaggiore with their relations, have shown signs and symptoms of Trichinella infection in their respective towns, and the infection was confirmed with FAT.

The muscle biopsies were obtained surgically from deltoid for parasitological diagnosis and for the isolation of the parasite in laboratory animals.

The fluorescent antibody test (FAT) employed was that of Ruitenberg et al. (1968).

The identification of Trichinella isolate has been carried out with isoenzymatic typing of 10 gene-enzyme systems (LDH, ME, 6PGD, G6PD, GOT, AK, PGM, ACON, MPI, GPI) according to the method described by Pozio (1987).

\section{Results}

It was possible to study 161 patients (from 1 to 73 years old; average age 35 years; no. of males 71), 149 by health centre of Salsomaggiore, 8 by Fidenza and Parma hospitals, and 4 in differents towns. All blood samples were taken 
50-55 days after the ingestion of infected meat. The results of the Fluorescent Antibody Test (FAT), total IgG, white cell count, percentage of eosinophilia, muscular enzymes (CPK, LDH, GOT, GPI) are presented in Tables I and II. All patients proved negative for specific IgM. The clinical signs and symptoms (diarrhoea, abdominal pain, vomiting, uveitis, periorbital and/or diffuse œdema, myalgia, exanthema, fever, headache, arthralgia) are reported in Table III. The duration of clinical symptoms was 3 days for 20 patients, between 3 and 30 days for 44 , and more for the others. Only 8 patients were hospitalized. There were no deaths.

TABLE I. - Essential laboratory data on 161 cases of human trichinellosis, 50-55 days post infection.

\begin{tabular}{lccr}
\hline $\begin{array}{c}\text { FAT } \\
\text { titre }\end{array}$ & $\begin{array}{c}\text { No. } \\
\text { of patients } \\
(\%)\end{array}$ & $\begin{array}{c}\% \\
\% \\
\text { eosinophilia }\end{array}$ & $\begin{array}{c}\text { No. } \\
\text { of patients } \\
(\%)\end{array}$ \\
\hline$<1 / 20$ & $6(4)$ & $0-2$ & $9(6)$ \\
$1 / 20$ & $13(8)$ & $3-6$ & $8(5)$ \\
$1 / 40$ & $16(10)$ & $7-10$ & $6(4)$ \\
$1 / 80$ & $26(16)$ & $11-15$ & $20(12)$ \\
$1 / 160$ & $3(2)$ & $16-20$ & $25(16)$ \\
$1 / 320$ & $10(6)$ & $21-30$ & $36(35)$ \\
$1 / 640$ & $9(6)$ & $31-40$ & $7(4)$ \\
$1 / 1280$ & $45(28)$ & & \\
$1 / 2560$ & $5(3)$ & & \\
$1 / 5120$ & $22(14)$ & & \\
$1 / 10240$ & $6(4)$ & & \\
\hline
\end{tabular}

Only three patients (two hospitalized and one not) accepted the muscle biopsy and all three were found parasitologically positive. From one of these biopsies we obtained a Trichinella isolate, through transmission in laboratory mouse. Isoenzymatic typing through 10 gene-enzyme systems (Pozio, 1987) showed that this isolate (code MHOM/IT/86/ISS53) had an electrophoretic behaviour like T. nelsoni reference strain (code MFEL/IT/75/ISS1).

Only a few people were treated with mebendazole (5 $\mathrm{mg} / \mathrm{kg}$ for 5 days), but with slow remission of symptomatology. Corticosteroid treatment was used only for patients with diffuse œedema and exanthema.

\section{Discussion}

The habit of eating minced raw horse meat is widespread only in Northern Italy. This fact explains the occurrence of trichinellosis outbreaks in the same area in Italy. Probably infected horses are frequent but the rarity of human infection is most likely due to the habit of most people to eat well cooked horse meat. 
TABle II. - White cell count, total IgG and muscular enzyme value on 161 cases of human trichinellosis, 50-55 days post-infection.

\begin{tabular}{|c|c|c|c|c|c|c|c|c|c|c|c|}
\hline $\begin{array}{l}\text { White cell } \\
\text { count } \\
\times \text { mmq }\end{array}$ & $\begin{array}{c}\text { No. of } \\
\text { patients } \\
(\%)\end{array}$ & $\begin{array}{c}\text { Total } \\
\text { IgG } \\
\text { IU /ml (1) }\end{array}$ & $\begin{array}{c}\text { No. of } \\
\text { patients } \\
(\%)\end{array}$ & $\underset{(2)}{\mathrm{CPK}}$ & $\begin{array}{l}\text { No. of } \\
\text { patients } \\
(\%)\end{array}$ & $\underset{(3)}{\mathrm{LDH}}$ & $\begin{array}{l}\text { No. of } \\
\text { patients } \\
(\%)\end{array}$ & $\begin{array}{c}\text { GOT } \\
(4)\end{array}$ & $\begin{array}{l}\text { No. of } \\
\text { patients } \\
(\%)\end{array}$ & $\begin{array}{c}\text { GPI } \\
(5)\end{array}$ & $\begin{array}{c}\text { No. of } \\
\text { patients } \\
(\%)\end{array}$ \\
\hline $\begin{array}{l}4000-6000 \\
6000-9000 \\
>9000\end{array}$ & $\begin{array}{l}28(17) \\
92(57) \\
41(25)\end{array}$ & $\begin{array}{l}<144 \\
144-200 \\
>200\end{array}$ & $\begin{array}{c}102(63) \\
51(32) \\
8(5)\end{array}$ & $\begin{array}{l}<100 \\
100-200 \\
>200\end{array}$ & $\begin{array}{l}46(29) \\
67(42) \\
48(30)\end{array}$ & $\begin{array}{l}<280 \\
281-400 \\
>400\end{array}$ & $\begin{array}{l}62(38) \\
84(52) \\
15(9)\end{array}$ & $\begin{array}{l}<40 \\
>40\end{array}$ & $\begin{array}{r}145(90) \\
16(10)\end{array}$ & $\begin{array}{l}<35 \\
>35\end{array}$ & $\begin{array}{r}121(75) \\
40(25)\end{array}$ \\
\hline
\end{tabular}

(1) Normal value $<144$. (2) Creatine phosphokinase, normal value 15-100IU. (3) Lactate dehydrogenase, normal value $<280$ IU. (4) Glutamate oxalacetate transaminase, normal value $<40$ IU. (5) Glutamate piruvate transaminase, normal value $<35$ IU.

TABLE III. - Clinical features in 161 patients with trichinellosis.

\begin{tabular}{lr}
\hline Signs and symptoms & $\begin{array}{c}\text { No. of patients } \\
(\%)\end{array}$ \\
\hline Fever $<38^{\circ} \mathrm{C}$ & $46(29)$ \\
$>38^{\circ}<40^{\circ} \mathrm{C}$ & $56(35)$ \\
$>40^{\circ} \mathrm{C}$ & $9(6)$ \\
Headache & $106(66)$ \\
Myalgia & $108(67)$ \\
Edema periorbital & $64(40)$ \\
Arthralgia & $36(22)$ \\
Abdominal pain & $65(40)$ \\
Uveitis & $42(26)$ \\
Diarrhoea after 10 days & $42(26)$ \\
Diarrhoea after 30 days & $12(7)$ \\
Vomiting & $23(14)$ \\
Exanthema & $15(9)$ \\
\end{tabular}


This has been the largest outbreak of trichinellosis in Italy, but it would seem that the infected horse meat had small numbers of parasites per gram: in fact some people ate about $500 \mathrm{~g}$ of raw horse meat, without showing severe clinical symptoms. Most of the symptoms disappeared in less than two weeks.

The isoenzymatic typing of the causal parasite as $T$. nelsoni allows to know the clinical and biological signs and symptoms of these parasite and therefore the place of the origin of the infected horse. The present knowledge of Trichinella species distribution (Shaikenov and Boev, 1983 ; Pozio, 1987), suggest Yugoslavia as the country of origin of the infected horse and not Poland.

The difficulty experienced by the physicians to make a correct diagnosis, resulted in a scarcity of clinical and biological data in the first stages of the disease. It is very difficult to find the source of infections and moreover it causes a delay in the proper treatment of the patients.

Fever, œdema, myalgia and headache were the most common signs and symptoms. Arthralgia was frequent. Uveitis was present in 42 patients $(26 \%)$ and most went to oculists for diagnosis. The abdominal syndrome (abdominal pain and diarrhoea) after ten days was probably related to enteritis due to an inflammatory reaction of the mucosa of the small intestine to adult worms. The diarrhoea after 30 days was probably caused by a delayed hypersensitivity reaction (Ozeretskovskaya and Tumolskaya, 1974).

Vomiting was present in 15 patients $(9 \%$ ), during the intestinal stage of the parasite. Exanthema was observed only in six cases $(4 \%)$. An increased eosinophil count was found in $94 \%$ of our cases. The serum concentrations of muscular enzymes were increased. The FAT tests were positive for $96 \%$ people with clinical and biological symptomatology. The negative results of specific IgM is probably caused to a low concentration of this immunoglobulin due to the long time (5055 days) passed between the ingestion of infected meat and the sampling of blood, and to a low parasitary load ingested by the patients. Also the use of FAT instead of ELISA can have had an influence. Van Knapen et al. (1982) detected with ELISA IgM in human sera even 11 months after infection, whilst the FAT yielded negative results. It is extremely improbable, due to the low incidence of trichinellosis in Italy, that the 161 patients, positives for $\operatorname{IgG}$, had been exposed to a previous Trichinella infection.

The clinical features of this outbreak of trichinellosis are very like those of the focus in Southern Italy in 1985, caused by the ingestion of wild boar meat (Pozio et al., 1986), where T. nelsoni was identified as the cause (Pozio, 1987).

The late use of proper treatment with mebendazole due to the delayed diagnosis (50-60 days after the ingestion of infected meat) has been responsible for the slow remission of signs and symptoms (Lapszewicz et al., 1969). Unfortunately we have not observed clinical improvement reported by Hennenkeuser et al. (1968). When the patients were treated with mebendazole, the nurse cell or " cyst " would have been completely formed, thus providing some protection for the parasite against the anthelmintics. Nevertheless some authors have shown the extraordinary efficacy of mebendazole against encysted larvae (38-48 days after infection) in 
laboratory animals (Thienpont et al., 1974) and in human trichinellosis (Sonnet and Thienpont, 1977).

Acknowledgements. - We are grateful to Dr M. Mercadante for the collection of some biological data, and to M. M. Amati for technical assistance.

We are also grateful to Dr R. B. Grifflths for revising the English text.

\section{REFERENCES}

Ancelle T., Dupouy-Camet J., Lavarde C., Lepierre J. : The 1985 trichinosis outbreaks due to horse meat in France. IXth International Congress of Infectious and Parasitic Diseases, Munich, July 20-26, 1986, No. 757.

Bourée P., Bouvier J. B., Passeron J., Gelanaud P., Dormount J. : Outbreak of trichinosis near Paris. Br. Med. J., 1979, 1, 1047-1049.

Hennekeuser H. H., Pabst K., Poeplow W., Gerok W. : Zur Klinik und Therapie der Trichinose: Beobachtungen an 47 Patienten während einer Epidemie. Dtsh. Med. Woshenschr., 1968, 93, 867-873.

Knapen F. van, Franchimont J. H., Verdonk A. R., Stumpf J., Undeutsch K. : Detection of specific immunoglobulins (IgG, IgM, IgA, IgE) and total IgE levels in human trichinosis by means of the enzyme-linked immunosorbet assay (ELISA). Am. J. Trop. Med. Hyg., 1982, 31, 973-976.

Lapszewicz A., Pawlowski Z., Gabryel P. Thiabendazole in human trichinellosis. Wiad. Parazytol., 1969, 15, 759-760.

Mantovani A., Filippini I., Bergomi S. : Indagini su un'epidemia di trichinellosi umana verificatasi in Italia. Parassitologia, 1980, 22, 107-134.

Мотука S. : Enquête épidémiologique à propos d'un foyer de trichinose humaine dans la région parisienne. Bull. Acad. Vet. France, 1976, 49, 95-99.

Ozeretskovskaya N. N., Tumolskaya N. I. : Clinical pattern and pathogenesis of the abdominal syndrome in trichinellosis. Trichinellosis, Intext, New-York, 1974, 389-398.

Parravicini M., Grampa A., Salmini G., Parravicini U., Dietz A., Montanari M. : Focolaio epidemico di trichinosi da carne di cavallo. G. Malat. Infet. Parassit., 1986, 38, 482-487.

Pozio E., Santagada G., Di Bari C. : Outbreak of trichinellosis in Southern Italy. Trans. Roy. Soc. Trop. Med. Hyg., 1986, 80, 997-998.

Pozıo E. : Isoenzymatic typing of 23 Trichinella isolates. Trop. Med. Parasitol., 1987, 38, 111-116.

Ruitenberg E. J., Kampelmacher E. H., Berkvens J. : The indirect fluorescent antibody technique in serodiagnosis of pigs infected with Trichinella spiralis. Neth. J. Vet. Sci., 1968, $1,143-153$.

Shaikenov B., Boev S. N. : Distribution of Trichinella species in the Old World. Wiad. Parazytol., 1983, 29, 595-608.

Sonnet J. J., Thienpont D. : The treatment of trichinosis with mebendazole. Acta Clin. Belg., $1977,32,297-302$.

Thienpont D., Vanparius O. F., Vandesteene R. : Anthelmintic and histopathological effects of mebendazole on Trichinella spiralis in the rat. Trichinellosis, Intext, New-York, 1974, pp. 515-527. 